\title{
Glial Cell Line-Derived Neurotrophic Factor Mediates the Desirable Actions of the Anti-Addiction Drug Ibogaine against Alcohol Consumption
}

\author{
Dao-Yao He, ${ }^{1 *}$ Nancy N. H. McGough, ${ }^{1 *}$ Ajay Ravindranathan, ${ }^{1}$ Jerome Jeanblanc, ${ }^{1}$ Marian L. Logrip, ${ }^{1,3}$ \\ Khanhky Phamluong, ${ }^{1}$ Patricia H. Janak, ${ }^{1,2,3}$ and Dorit Ron ${ }^{1,2,3}$ \\ ${ }^{1}$ Ernest Gallo Research Center, ${ }^{2}$ Department of Neurology, ${ }^{3}$ Neuroscience Graduate Program, University of California, San Francisco, Emeryville, California \\ 94608
}

\begin{abstract}
Alcohol addiction manifests as uncontrolled drinking despite negative consequences. Few medications are available to treat the disorder. Anecdotal reports suggest that ibogaine, a natural alkaloid, reverses behaviors associated with addiction including alcoholism; however, because of side effects, ibogaine is not used clinically. In this study, we first characterized the actions of ibogaine on ethanol selfadministration in rodents. Ibogaine decreased ethanol intake by rats in two-bottle choice and operant self-administration paradigms. Ibogaine also reduced operant self-administration of ethanol in a relapse model. Next, we identified a molecular mechanism that mediates the desirable activities of ibogaine on ethanol intake. Microinjection of ibogaine into the ventral tegmental area (VTA), but not the substantia nigra, reduced self-administration of ethanol, and systemic administration of ibogaine increased the expression of glial cell line-derived neurotrophic factor (GDNF) in a midbrain region that includes the VTA. In dopaminergic neuron-like SHSY5Y cells, ibogaine treatment upregulated the GDNF pathway as indicated by increases in phosphorylation of the GDNF receptor, Ret, and the downstream kinase, ERK1 (extracellular signal-regulated kinase 1). Finally, the ibogaine-mediated decrease in ethanol selfadministration was mimicked by intra-VTA microinjection of GDNF and was reduced by intra-VTA delivery of anti-GDNF neutralizing antibodies. Together, these results suggest that GDNF in the VTA mediates the action of ibogaine on ethanol consumption. These findings highlight the importance of GDNF as a new target for drug development for alcoholism that may mimic the effect of ibogaine against alcohol consumption but avoid the negative side effects.
\end{abstract}

Key words: addiction; alcohol; growth factor; neurotrophic; self-administration; ventral tegmental area

\section{Introduction}

Drug abuse and alcoholism are serious and costly health problems. Unfortunately, few medications have proven effective for treating the disease states of addiction and dependence. Ibogaine, a natural alkaloid extracted from the root bark of the African shrub Tabernanthe Iboga, has attracted attention because of its reported ability to reverse human addiction to multiple drugs of abuse, including alcohol (Popik et al., 1995; Mash et al., 1998; Vastag, 2002). Human anecdotal reports assert that a single administration of ibogaine reduces craving for opiates and cocaine

\footnotetext{
Received July 24, 2003; revised Nov. 28, 2004; accepted Nov. 29, 2004.

This research was supported by funds provided by the State of California for medical research on alcohol and substance abuse through the University of California, San Francisco (P.H.J., D.R.), by the National Institute on Alcohol and Drug Abuse and Alcoholism Grant R01 AA 014366 (D.R., P.H.J.), and by the Department of the Army, Grant DAMD17-0110802 (D.R.) for which the U.S. Army Medical Research Acquisition Activity, 820 Chandler Street, Fort Detrick, MD 21702-5014, is the awarding and administering acquisition office. We thank Peter Traum and Viktor Kharazia for their contributions and our colleagues for critical reading of this manuscript.

The content of the information represented does not necessarily reflect the position or the policy of the Government, and no official endorsement should be inferred.

${ }^{*}$ D.-Y.H. and N.N.H.M. contributed equally to this work.

Correspondence should be addressed to either senior author, Dr. Dorit Ron or Dr. Patricia H. Janak, 5858 Horton Street, Suite 200, Emeryville, CA 94608. E-mail: dorit@itsa.ucsf.edu or pjanak@itsa.ucsf.edu. DOI:10.1523/JNEUROSCI.3959-04.2005

Copyright $\odot 2005$ Society for Neuroscience $\quad$ 0270-6474/05/250619-10\$15.00/0
}

for extended periods of time and reduces opiate withdrawal symptoms (Sheppard 1994; Mash et al., 1998; Alper et al., 1999). Studies also suggest that ibogaine attenuates drug- and ethanolinduced behaviors in rodents. For example, ibogaine reduces operant self-administration of heroin in rats, as well as naloxoneprecipitated withdrawal in morphine-dependent rats (Glick et al., 1992; Dworkin et al., 1995). Administration of ibogaine decreases cocaine-induced locomotor activity and reduces cocaine self-administration in rats (Cappendijk and Dzoljic, 1993) and mice (Sershen et al., 1994). Rezvani et al. (1995) reported that ibogaine reduces ethanol self-administration in alcohol-preferring selected lines of rats; however, the effects of ibogaine have not been tested in an operant procedure in which oral ethanol reinforces lever press behavior. Our first aim was to extend the characterization of the effects of ibogaine on ethanol self-administration to the operant procedure, including a test of the effects of ibogaine on reinstatement of ethanol self-administration after a period of extinction.

Despite its attractive properties, ibogaine is not approved as an addiction treatment because of the induction of side effects such as hallucinations. In addition, ibogaine at high doses causes degeneration of cerebellar Purkinje cells (O'Hearn and Molliver, 1993, 1997) and whole-body tremors and ataxia (Glick et al., 1992; O'Hearn and Molliver, 1993) in rats. In an attempt to dif- 
ferentiate between the desirable and undesirable actions of ibogaine, we set out to elucidate the molecular pathway that specifically mediates the effect of the drug on ethanol consumption. Our hope was that identification of this pathway would reveal possibilities for new pharmacological approaches to treat alcoholism that would not have the undesirable side effects of ibogaine.

All drugs of abuse, including alcohol, activate the "reward" neurocircuitry (Koob et al., 1998; Spanagel and Weiss, 1999). One of the major brain regions in this pathway is the ventral tegmental area (VTA). The VTA is the brain site at which many biochemical neuroadaptations induced by repeated drugs of abuse, including ethanol, have been observed. For example, longterm ethanol exposure increases levels of tyrosine hydroxylase (TH), glial fibrillary acidic protein, and the NR1 subunit of the NMDA receptor and decreases levels of neurofilament protein and the $\alpha 1$ subunit of the $\mathrm{GABA}_{\mathrm{A}}$ receptor in the VTA (Ortiz et al., 1995; Charlton et al., 1997). Furthermore, several studies suggest that the VTA may also be the site of action for reversal of the neuroadaptations that lead to the development of addiction. For example, infusion of brain-derived neurotrophic factor (BDNF) into the VTA reverses morphine-induced elevations of TH (Berhow et al., 1995). In addition, Messer et al. (2000) reported that chronic exposure to cocaine and morphine decreases the level of Ret phosphorylation, and thus activation, of the glial cell linederived neurotrophic factor (GDNF) pathway in the VTA, whereas infusion of GDNF into the VTA dose-dependently reverses the increase in $\mathrm{TH}$ immunoreactivity observed after morphine injection. Furthermore, intra-VTA GDNF treatment blocks the behavioral effects of repeated exposure to cocaine (Messer et al., 2000). Thus, we postulated that the VTA may be, at least in part, the site of action of ibogaine. Therefore, we tested the effects of intra-VTA ibogaine administration on ethanol consumption and set out to determine the molecular effects of ibogaine in the midbrain and in SHSY5Y cells, a dopaminergic neuroblastoma cell line (Biedler et al., 1978). Our studies suggest that GDNF in the midbrain region mediates the ibogaine-induced reduction in ethanol consumption.

\section{Materials and Methods}

\section{Materials}

Ibogaine- $\mathrm{HCl}$, phosphatidylinositol phospholipase C (PI-PLC), Wortmannin and Latrunculin B were purchased from Sigma (St. Louis, MO). Human and rat GDNF and anti-GDNF monoclonal neutralizing antibodies were purchased from R \& D Systems (Minneapolis, MN). The inhibitors U0126 and PD98059 were purchased from Calbiochem (La Jolla, CA). Protease inhibitor mixture was purchased from Roche Applied Science (Indianapolis, IN). Anti-phosphotyrosine antibodies were purchased from BD Transduction Laboratories (San Diego, CA). AntiRet, anti-GDNF family receptor $\alpha 1$ (anti-GFR $\alpha 1$ ), anti-extracellular signal-regulated kinase 2 (ERK2), anti-phosphoERK1/2, anti-tyrosine kinase (Trk) B, anti-phospho-Trk antibodies, and mouse IgG were purchased from Santa Cruz Biotechnology (Santa Cruz, CA). Trizol reagent was purchased from Invitrogen (Carlsbad, CA). GDNF Emax Immunoassay System, Reverse Transcription System, and PCR Master Mix were purchased from Promega (Madison, WI). Primers for PCR were synthesized by BioSource International (Camarillo, CA). Fluoro-Jade was purchased from Histo-Chem (Jefferson, AZ). Artificial CSF (aCSF) was purchased from CMA Microdialysis (North Chelmsford, MA).

\section{Animals}

Adult male Long-Evans rats were purchased from Harlan (Indianapolis, IN); C57BL/6 mice were purchased from Jackson Laboratories (Bar Harbor, ME). Rodents were housed in ventilated polycarbonate cages with food and water available ad libitum except as noted below, on a standard $12 \mathrm{hr}$ light/dark schedule with lights on at 6 A.M. Subjects were group housed for all studies, except for the ethanol two-bottle and operant self-administration studies, for which they were housed singly. All studies were conducted with approval by the Gallo Center Institutional Animal Care and Use Committee and were in accordance with PHS Policy on Humane Care and Use of Laboratory Animals, Office of Laboratory Animal Welfare, National Institutes of Health, revised 2002.

\section{Ibogaine preparation and treatment for in vivo studies in mice} and rats

Ibogaine- $\mathrm{HCl}$ was dissolved in water to create a stock solution. The stock solution was diluted further by appropriate vehicle solution (saline or aCSF) as needed. Systemic injections were intraperitoneal and given in injection volumes of $2 \mathrm{ml} / \mathrm{kg}$ for rats and $1 \mathrm{ml} / 100 \mathrm{gm}$ for mice at a concentration of 20 or $40 \mathrm{mg} / \mathrm{kg}$. The $40 \mathrm{mg} / \mathrm{kg}$ dose of ibogaine has been reported previously to reduce cocaine and heroin self-administration (Glick et al., 1992; Cappendijk and Dzoljic, 1993; Dworkin et al., 1995). This dose of ibogaine is not toxic to cells because it was shown not to produce Purkinje cell death (Molinari et al., 1996).

\section{Ibogaine effects on gene expression in vivo}

Male C57BL/6 mice or Long-Evans rats were habituated with three saline injections over $3 \mathrm{~d}$ followed by intraperitoneal administration of 40 $\mathrm{mg} / \mathrm{kg}$ ibogaine. The animals were killed at the indicated time point, and brain regions were excised and stored at $-80^{\circ} \mathrm{C}$ until use for analysis of GDNF expression by RT-PCR or by microarray.

\section{Microarray analysis}

RNA was isolated using the RNeasy protocol (Qiagen, Chatworth, CA) as per manufacturer protocols. In each case the specific brain regions (e.g., midbrain) from five mice were pooled together to form a single sample. After isolation, the RNA was reverse-transcribed using cytokine-specific primers, avian myeloblastosis virus reverse transcriptase, and ${ }^{33} \mathrm{P}$ labeled dCTP to generate radio-labeled cDNA. This cDNA was then column purified and hybridized to mouse cytokine expression arrays $(\mathrm{R}$ \& D Systems) for $16 \mathrm{hr}$ at $65^{\circ} \mathrm{C}$ as per manufacturer protocols. These arrays contain $\sim 500$ different cDNAs related to cytokine signaling. The blots were then washed, and the hybridization signal was visualized using a PhosphorImager (Molecular Dynamics, Sunnyvale, CA). The hybridization signal for each gene was normalized to the mean level of expression of four housekeeping genes ( $\beta$-actin, GPDH, $\alpha$-tubulin, and cyclophilin). Genes that showed a minimum change of $40 \%$ in at least three of five comparisons (ibogaine vs vehicle) were flagged as either an increase or a decrease.

\section{$R T-P C R$}

Total RNA was isolated using Trizol reagent and reverse transcribed using the Reverse Transcription System kit with the oligo (dT) 15 primer at $42^{\circ} \mathrm{C}$ for $30 \mathrm{~min}$. GDNF, actin, or GPDH expression was analyzed by RT-PCR. The GDNF primers were based on the coding frame of the human GDNF gene: upstream, 5' -TGC CAG AGG ATT ATC CTG ATC AGT TCG ATG-3'; downstream, ${ }^{\prime}{ }^{\prime}$-TTG TCG TAC GTT GTC TCA GCT GCA TCG CAA- $3^{\prime}$. The actin primers were based on the human actin gene: upstream, 5' -TCA TGA AGT GTG ACG TTG ACA TC-3'; downstream, 5'-AGA AGC ATT TGC GGT GGA CGA TG-3'. The $G P D H$ primers were based on the rat GPDH gene: upstream, $5^{\prime}$-TGA AGG TCG GTG TCA ACG GAT TTG GC-3'; downstream, 5' -CAT GTA GGC CAT GAG GTC CAC CAC-3'. PCR conditions were optimized to specifically ensure that the amplification reactions were within the linear range by testing a range of 25-40 PCR cycles. The optimal numbers of cycles used were as follows: 30 cycles for controls GPDH and actin and 35 cycles for GDNF. After completion of PCR, $10 \mu \mathrm{l}$ of each product was separated by $1.8 \%$ agarose gel in Tris/acetic acid/EDTA buffer with 0.25 $\mu \mathrm{g} / \mathrm{ml}$ ethidium bromide, photographed by Eagle Eye II (Stratagene. La Jolla, CA), and quantified by NIH Image 1.61.

\section{Cell culture}

SHSY5Y human neuroblastoma cells were grown in DMEM containing $10 \%$ fetal bovine serum (FBS) plus $100 \mathrm{U} / \mathrm{ml}$ penicillin and $100 \mu \mathrm{g} / \mathrm{ml}$ streptomycin. Before experiments, the medium was replaced with DMEM containing 1\% FBS. 
Effects of ibogaine on cell toxicity in vivo and in vitro

For in vivo testing, male C57BL/6 mice were injected with ibogaine (40 $\mathrm{mg} / \mathrm{kg}$, i.p.). The mice were subsequently anesthetized using carbon dioxide and perfused intracardially with $4 \%$ paraformaldehyde $12 \mathrm{hr}$ after ibogaine administration. The skull was then removed and the brain postfixed in paraformaldehyde. After sucrose impregnation, brains were blocked and $25-\mu \mathrm{m}$-thick coronal sections were generated, placed on gelatinized slides, and stained with Fluoro-Jade. Briefly, sections were dehydrated in $100 \%$ ethanol for $3 \mathrm{~min}$ followed by $1 \mathrm{~min}$ in $70 \%$ ethanol. After a $1 \mathrm{~min}$ wash in distilled water, the sections were treated with $0.06 \%$ $\mathrm{KMnO}_{4}$ with constant agitation for $15 \mathrm{~min}$. After a $1 \mathrm{~min}$ wash in distilled water, the sections were placed in a solution composed of $0.001 \%$ FluoroJade in $0.1 \%$ acetic acid for $15 \mathrm{~min}$. The slides were washed three times with distilled water, dried, and coverslipped with a mixture of distyrene, tricresyl phosphate, and xylene (DPX). Sections were visualized with a Leica fluorescent microscope using an FITC filter and a $10 \times$ and $20 \times$ objective.

To assay cell death in vitro, SHSY5Y cells were treated with $10 \mu \mathrm{M}$ ibogaine for $24 \mathrm{hr}$. Parallel cultures were treated with $4 \mu \mathrm{M}$ Wortmannin (PI3 kinase inhibitor) or $2 \mu \mathrm{M}$ Latrunculin B (actin polymerization inhibitor) for $90 \mathrm{~min}$. After treatment, cells were fixed in $4 \%$ paraformaldehyde for $3 \mathrm{~min}$ and placed in 100\% ethanol for $1 \mathrm{~min}$, followed by a 1 min distilled water wash. The cells were then treated in $\mathrm{KMnO}_{4}$ for 3 min followed by $5 \mathrm{~min}$ incubation in a $0.001 \%$ acetylated Fluoro-Jade solution. After three washes in distilled water, the cells were cleared in xylene for $1 \mathrm{~min}$, coverslipped with DPX, and visualized using a Leica fluorescent microscope with a FITC filter and $10 \times$ and $20 \times$ objectives.

\section{Immunoprecipitation}

Cells were collected and lysed in RIPA buffer (50 mm Tris-Cl, pH 7.6, 150 $\mathrm{mm} \mathrm{NaCl}, 1 \% \mathrm{NP}-40,0.1 \%$ SDS, $0.5 \%$ sodium deoxycholate, $2 \mathrm{~mm}$ EDTA, protease inhibitor mixture, and $10 \mathrm{~mm}$ sodium orthovanadate). Homogenates were incubated with $5 \mu \mathrm{g}$ anti-Ret antibody in TBS-T buffer (20 mm Tris-HCl, pH 7.6, $137 \mathrm{~mm} \mathrm{NaCl}$, and 0.1\% Tween 20) overnight at $4^{\circ} \mathrm{C}$, followed by $2 \mathrm{hr}$ incubation with Protein $\mathrm{G}$ agarose. Samples were separated on an SDS-PAGE gel for Western blot analysis.

\section{ELISA}

GDNF secretion in the medium was detected using the GDNF Emax Immunoassay System according to Balkowiec and Katz (2000). GDNF concentration was interpolated from the standard curves (linear range of $15.6-1000 \mathrm{pg} / \mathrm{ml})$.

\section{Behavioral studies}

Effects of ibogaine on ethanol and sucrose self-administration in the twobottle preference test. Male Long-Evans rats were allowed continuous access to two bottles, one containing $10 \%$ ethanol (10E) in tap water and the other containing tap water. Two months later, 20 or $40 \mathrm{mg} / \mathrm{kg}$ ibogaine or vehicle was injected intraperitoneally at 3 P.M., $3 \mathrm{hr}$ before the start of the dark cycle; ethanol and water intake were measured $24 \mathrm{hr}$ later. Each subject received each dose, with one injection per week. Next, subjects were exposed to two bottles, one containing 10\% sucrose (10S) in tap water and the other containing tap water. Four days later, the effects of $40 \mathrm{mg} / \mathrm{kg}$ ibogaine were determined as above.

Effects of ibogaine and GDNF on ethanol operant self-administration: operant ethanol self-administration training. The self-administration chamber contained two levers: an active lever, for which presses resulted in delivery of $0.1 \mathrm{ml}$ of fluid reward, and an inactive lever, for which responses were counted but no programmed events occurred. Rats were water restricted and then trained to lever press for a $10 \mathrm{~S} / 10 \mathrm{E}$ reinforcer solution in three overnight sessions. On the fourth day, rats were allowed ad libitum access to water in the home cage and were transferred to $1 \mathrm{hr}$ daily sessions, wherein responses were reinforced with $5 \mathrm{~S} / 10 \mathrm{E}$ on a fixedratio 3 (FR3) schedule. Sucrose was phased out of the reinforcer solution over the next $7 \mathrm{~d}$ until the solution consisted of $10 \mathrm{E}$ only. Experimental manipulations began after 30 sessions when stable $10 \mathrm{E}$ intake of $\geq 0.4$ $\mathrm{gm} / \mathrm{kg}$ ethanol was attained.

Effects of systemic ibogaine on ethanol self-administration. The mean intake by the group receiving intraperitoneal ibogaine was $0.45 \pm 0.13$ $\mathrm{gm} / \mathrm{kg}$. Intakes at these levels produce measurable levels in blood (Weiss et al., 1993) and brain (Ferraro et al., 1991). Half of the subjects received ibogaine ( $40 \mathrm{mg} / \mathrm{kg}$, i.p.), whereas the other half received vehicle, $3 \mathrm{hr}$ before the start of an ethanol self-administration session. This time interval was chosen to mimic the time interval between ibogaine injection and the start of the dark cycle in the two-bottle preference study. One week later, the drug treatments were reversed, such that each subject received both ibogaine and vehicle treatments.

Effects of systemic ibogaine administration on ethanol self-administration after a period of extinction (ethanol reinstatement). The eight rats used in the operant self-administration study were also used to study ethanol selfadministration after a period of extinction. After a period of stable responding for ethanol, rats underwent extinction in which no ethanol was delivered after active lever responses. After 12-15 extinction sessions, rats met the extinction criteria (fewer than five presses per session). Half of the rats were then injected with ibogaine ( $40 \mathrm{mg} / \mathrm{kg}$, i.p.) or vehicle $3 \mathrm{hr}$ before the reinstatement test session, in which lever presses on the ethanol-associated lever resulted in the delivery of $0.1 \mathrm{ml}$ of $10 \mathrm{E}$ (FR1 schedule). After an additional 2 weeks of extinction sessions, a second reinstatement test session was conducted with the drug treatments reversed, such that every subject received both a vehicle and an ibogaine treatment.

Effects of intra-VTA microinjection of ibogaine on ethanol selfadministration. Ethanol self-administration was established as described above in a separate group of rats; these subjects attained a mean daily intake of ethanol of $0.62 \pm 0.07 \mathrm{gm} / \mathrm{kg}$. Bilateral guide cannulas $(26$ gauge, Plastics One, Roanoke, VA) were implanted into the VTA (5.6 $\mathrm{mm}$ posterior to bregma, $1.0 \mathrm{~mm}$ mediolateral, $8.0 \mathrm{~mm}$ ventral to the skull surface). After 7-10 d recovery, sham injections were conducted before ethanol self-administration sessions to habituate subjects to the microinjection procedure. Next, ibogaine $[0.1 \mu \mathrm{M} / 0.5 \mu \mathrm{l}(0.05 \mathrm{pmol}), 1$ $\mu \mathrm{M} / 0.5 \mu \mathrm{l}(0.5 \mathrm{pmol})$, and $10 \mu \mathrm{M} / 0.5 \mu \mathrm{l}(5.0 \mathrm{pmol})]$ or aCSF $(0.5 \mu \mathrm{l})$ was injected into the VTA of gently restrained rats at a rate of $0.1 \mu \mathrm{l} / \mathrm{min}$ via an internal injection cannula extending $0.5 \mathrm{~mm}$ beyond the guide cannula tip. Injection cannulas were left in place for an additional $1 \mathrm{~min}$ to allow for diffusion of the drug. Rats were placed in the selfadministration chambers 3,24 , and $48 \mathrm{hr}$ after injection for a $1 \mathrm{hr}$ selfadministration session. All subjects received each concentration, with the order of injections counterbalanced across subjects. Subjects received one injection per week.

Effects of intra-substantia nigra microinjection of ibogaine on ethanol self-administration. The effects of $10 \mu \mathrm{M} / 0.5 \mu \mathrm{l}$ (5.0 pmol) ibogaine microinjected into the substantia nigra were determined as described above for the VTA in a separate group of subjects trained to self-administer ethanol as described above. This group attained a mean daily intake of ethanol of $0.67 \pm 0.09 \mathrm{gm} / \mathrm{kg}$. The surgical coordinates for cannula placement were $5.2 \mathrm{~mm}$ posterior to bregma, $2.8 \mathrm{~mm}$ mediolateral, $6.7 \mathrm{~mm}$ ventral to the skull surface; the injector tip extended $0.5 \mathrm{~mm}$ beyond the guide cannula tip. Three hours after injection, rats were placed in the self-administration chambers for a $1 \mathrm{hr}$ self-administration session.

Effects of intra-VTA microinjection of GDNF on ethanol selfadministration. Ethanol self-administration was established as described above in a separate group of rats. These subjects attained a mean daily intake of ethanol of $0.24 \pm 0.05 \mathrm{gm} / \mathrm{kg}$. Bilateral guide cannulas (26 gauge, Plastics One) were implanted in the VTA $(5.6 \mathrm{~mm}$ posterior to bregma, $1.0 \mathrm{~mm}$ mediolateral, $8.0 \mathrm{~mm}$ ventral to the skull surface). After 7-10 d recovery, sham injections were conducted before ethanol selfadministration sessions to habituate subjects to the microinjection procedure. Next, GDNF ( $5 \mu \mathrm{g} / 1 \mu \mathrm{l}$ per side) or aCSF $(1 \mu \mathrm{l})$ was injected into the VTA of gently restrained rats at a rate of $0.5 \mu \mathrm{l} / \mathrm{min}$ via an internal injection cannula extending $0.5 \mathrm{~mm}$ beyond the guide cannula tip. Injection cannulas were left in place for an additional $1 \mathrm{~min}$ to allow for diffusion of the drug. Ten minutes after injection, rats were placed in the self-administration chambers for a $1 \mathrm{hr}$ self-administration session. All subjects received both aCSF and GDNF treatment. Subjects received one injection per week.

Effects of intra-VTA administration of anti-GDNF neutralizing antibodies on the reduction of ibogaine reduction in ethanol self-administration. In an additional group of rats, ethanol self-administration was established as described above. Next, bilateral osmotic pump guide cannulas (Plastics One) were implanted in the VTA (5.6 mm posterior to bregma, 1.0 
$\mathrm{mm}$ mediolateral, $8.5 \mathrm{~mm}$ ventral to the skull surface). After $7 \mathrm{~d}$ recovery, subjects were given $10-15$ training sessions to allow recovery of baseline levels of ethanol self-administration (rats in the control group consumed $0.65 \pm 0.11 \mathrm{gm} / \mathrm{kg}$, whereas rats in the experimental group consumed $0.66 \pm 0.08 \mathrm{gm} / \mathrm{kg}$ ). An osmotic minipump (Alzet, Palo Alto, CA) was then connected to each of the two guide cannulas and implanted subcutaneously for continuous infusion of either anti-GDNF neutralizing antibodies ( $600 \mathrm{ng} / 12 \mu \mathrm{l}$ per side per day) or mouse IgG (600 ng/12 $\mu \mathrm{l}$ per side per day). Two days later, $1 \mathrm{hr}$ daily ethanol self-administration sessions resumed for a $10 \mathrm{~d}$ testing period. On the eighth day of the 10 day self-administration testing period, rats received an intraperitoneal injection of ibogaine $(40 \mathrm{mg} / \mathrm{kg})$.

\section{Histology}

Locations of cannulas were verified in $50 \mu \mathrm{m}$ sections stained with thionin. Only data from subjects with cannulas located in the region of interest were included in the analyses.

\section{Data analysis}

Student's $t$ test was used to evaluate differences in in vivo gene expression and for the biochemical data. Two-bottle preference measures and ethanol self-administration data were analyzed by one- or two-way ANOVA with repeated measures. $F$ values attaining significance were evaluated further by Student-Newman-Keul's method. Latency data were analyzed by the Wilcoxon matched-pairs test. $p<0.05$ was regarded as statistically significant for all tests.

\section{Results}

Systemic and intra-VTA administration of ibogaine decrease self-administration of ethanol

We first set out to confirm that ibogaine administration attenuates ethanol self-administration by testing the effects of systemic injection of $40 \mathrm{mg} / \mathrm{kg}$ ibogaine on voluntary ethanol consumption in rats allowed continuous access to ethanol in the home cage. The $40 \mathrm{mg} / \mathrm{kg}$ dose was chosen because it has been reported to reduce cocaine and heroin self-administration (Glick et al., 1992; Cappendijk and Dzoljic, 1993; Dworkin et al., 1995) without evidence of neurotoxicity (Molinari et al., 1996). Under conditions of continuous access to ethanol in the home cage, the acute administration of ibogaine reduced both intake of (Fig. 1A) and preference for (Fig. $1 B$ ) ethanol. Ibogaine did not decrease water intake; as has been reported (Rezvani et al., 1995), there was an increase in water intake after ibogaine, but this increase was significant only for the $20 \mathrm{mg} / \mathrm{kg}$ dose. Total volume of fluid consumed was significantly increased for the $20 \mathrm{mg} / \mathrm{kg}$ dose but was not significantly changed after $40 \mathrm{mg} / \mathrm{kg}$ ibogaine (vehicle, $31.44 \pm 1.6 \mathrm{ml} ; 20 \mathrm{mg} / \mathrm{kg}, 43.11 \pm 4.9 \mathrm{ml} ; 40 \mathrm{mg} / \mathrm{kg}, 27.5 \pm 2.2$ $\mathrm{ml})$. In addition, no effect of ibogaine on preference for sucrose was observed (Fig. 1C).

Next, we tested the effects of ibogaine in an ethanol operant self-administration paradigm. Ibogaine ( $40 \mathrm{mg} / \mathrm{kg}$, i.p.) injection $3 \mathrm{hr}$ before the behavioral session decreased responding at the ethanol-paired lever and had no effect on inactive lever responding (Fig. 1D). We also tested the effect of ibogaine in an ethanol reinstatement paradigm in which subjects were allowed access to ethanol after a period of extinction. This procedure resulted in an enhancement of ethanol intake relative to the amount obtained before extinction (Fig. 1E, baseline vs saline). Enhanced intake after a period of abstinence is used as an animal model of drinking after relapse and may model the high intakes observed after relapse in humans (Koob, 2000; McBride and Li, 1998). As shown in Figure $1 E$, ibogaine reduced the enhanced ethanol intake observed after a period of extinction. This effect was also apparent when the number of lever presses was examined during the reinstatement test, as shown in Figure $1 F$. Ibogaine significantly decreased responding for ethanol when made available after a pe-
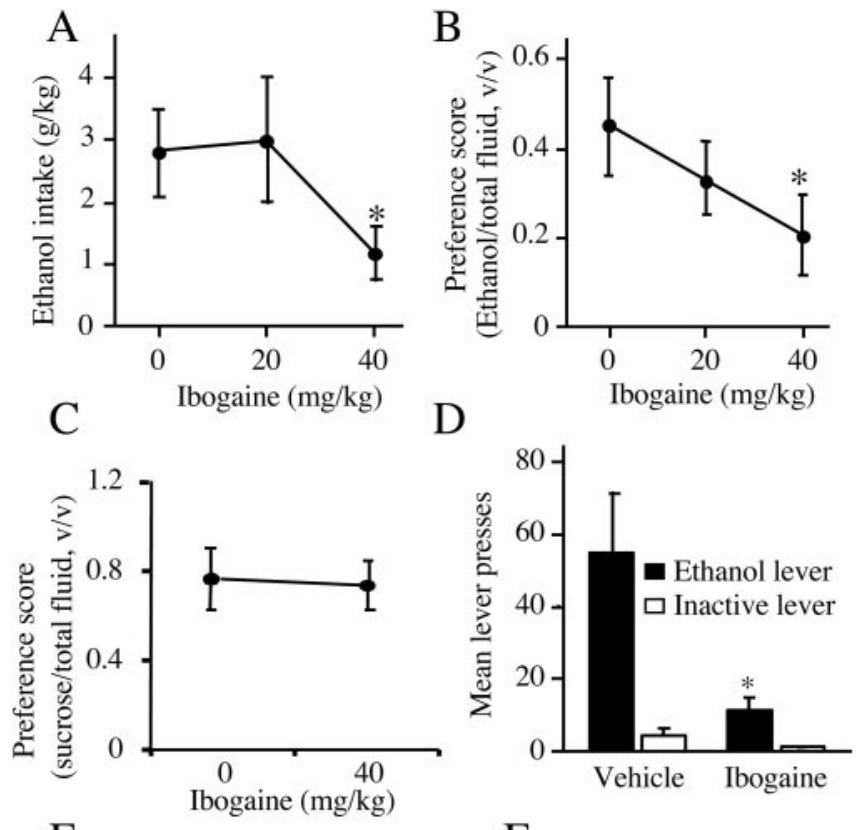

$\mathrm{E}$

$\mathrm{F}$

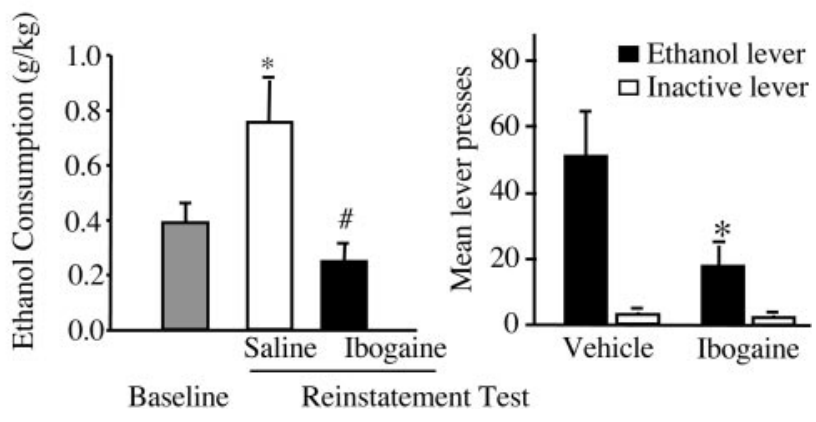

Figure 1. Ibogaine decreases ethanol consumption. $A$, lbogaine decreased ethanol consumption expressed as mean \pm SEM grams of ethanol per kilogram body weight during continuous access to both ethanol and water when intake was measured $24 \mathrm{hr}$ after an acute injection $\left(F_{(2,16)}=5.12 ; p<0.02\right) .{ }^{*} p<0.05$ compared with vehicle treatment $(n=9)$. $B$, Ibogaine treatment decreased ethanol preference expressed as mean milliliters of ethanol/(ml ethanol $+\mathrm{ml}$ water $) \pm \operatorname{SEM}\left(F_{(2,16)}=7.83 ; p<0.005\right)$. ${ }^{*} p<0.05$ compared with vehicle treatment $(n=9)$. C, Ibogaine did not affect sucrose preference, expressed as mean milliliters of sucrose $/\left(\mathrm{ml}\right.$ sucrose $+\mathrm{ml}$ water) $\pm \mathrm{SEM}$, measured $24 \mathrm{hr}$ after injection $\left(F_{(1,8)}=0.02 ; p=\right.$ $0.88)(n=9)$. $D$, Ibogaine attenuated operant ethanol self-administration in rats. Systemic ibogaine injected $3 \mathrm{hr}$ before the session reduced responding for oral ethanol at the ethanolpaired lever but not the inactive lever (main effect of treatment: $F_{(1,7)}=5.77, p<0.05$; main effect of lever: $F_{(1,7)}=15.83, p<0.006$; treatment $\times$ lever interaction: $F_{(1,7)}=5.78, p<$ $0.05]$. Ethanol was delivered on an FR3 reinforcement schedule. Data are shown as mean \pm SEM. ${ }^{*} p<0.05$ compared with active lever responding after vehicle treatment $(n=8)$. $E$, Enhanced ethanol intake after a period of extinction was reduced by ibogaine injected $3 \mathrm{hr}$ before the reinstatement test session (main effect of treatment: $F_{(2,12)}=10.07, p<0.03$ ). Data are shown as mean \pm SEM. ${ }^{*} p<0.02$ compared with baseline responding before extinction; ${ }^{\#} p<0.002$ compared with vehicle injection $(n=8)$ ). $F$, Data from $E$ expressed as number of lever presses on the ethanol and inactive levers at reinstatement test. Ibogaine injected $3 \mathrm{hr}$ before the reinstatement test session reduced responding for ethanol at the active lever but not the inactive lever (main effect of treatment: $F_{(1,6)}=11.16, p<0.02$; main effect of lever: $F_{(1,6)}=12.63, p<0.02$; treatment $\times$ leverinteraction: $\left.F_{(1,6)}=11.08, p<0.02\right)$. Ethanol was delivered on an FR1 reinforcement schedule. Data are shown as mean \pm SEM. ${ }^{*} p<0.02$ compared with active lever responding after vehicle injection $(n=7)$.

riod of extinction but had no effect on inactive lever responding (Fig. $1 F$ ). Importantly, the latency to the first lever press after ibogaine treatment was not different from that after vehicle for the findings presented in Figure 1, $D$ and $F$ (Table 1), indicating 
Table 1. Latency (in seconds) to first press is not significantly altered by ibogaine or GDNF treatment ${ }^{a}$

\begin{tabular}{lcc}
\hline Experiment & Mean \pm SEM & Median (minimum, maximum) \\
\hline $\begin{array}{l}\text { Ethanol self-administration } \\
\quad \text { Intraperitoneal vehicle }\end{array}$ & $113.4 \pm 48.3$ & $67.4(7.5,439.4)$ \\
$\quad$ Intraperitoneal ibogaine & $86.6 \pm 17.8$ & $86.6(13.6,191.4)$ \\
Ethanol relapse & & \\
$\quad$ Intraperitoneal vehicle & $411.6 \pm 139.4$ & $427.5(21.8,248.7)$ \\
$\quad$ Intraperitoneal ibogaine & $163.0 \pm 54.7$ & $106.0(27.6,461.9)$ \\
Ethanol self-administration & & \\
$\quad$ Intra-VTA ACSF & $102.95 \pm 19.23$ & $98.78(33.7,207.1)$ \\
$\quad$ Intra-VTA ibogaine $(10 \mu \mathrm{M})$ & $92.69 \pm 22.14$ & $63.71(17.1,205.5)$ \\
Ethanol self-administration & & \\
$\quad$ Intra-VTA ACSF & $176.43 \pm 27.10$ & $153.98(27.6,295.6)$ \\
$\quad$ Intra-VTA GDNF & $169.70 \pm 30.23$ & $145.75(64.8,312.7)$ \\
\hline
\end{tabular}

${ }^{a}$ Wilcoxon matched-pairs test; all $p>0.05$.

no ibogaine-induced impairment in initiating or completing the lever-press response.

Because the VTA is both a major component of the brain reward circuit (Koob et al., 1998) and a site at which numerous adaptations to ethanol have been noted (Ortiz et al., 1995), we tested whether ibogaine acts directly within the VTA to inhibit ethanol self-administration. Microinjection of ibogaine [0.1-10.0 $\mu \mathrm{M}(0.05-5 \mathrm{pmol})]$ into the VTA $3 \mathrm{hr}$ before the selfadministration session dose-dependently decreased responding at the ethanol-paired lever (Fig. 2A) but did not affect inactive lever responding (data not shown). The behaviorally effective concentration of $10 \mu \mathrm{M}$ did not affect latency to the first press (Table 1), indicating no suppressant effect of intra-VTA ibogaine on locomotor activity. Interestingly, intra-VTA activities of ibogaine were found to be long-lasting because lever pressing for ethanol did not return to baseline levels within $48 \mathrm{hr}$ of injection of the $10 \mu \mathrm{M}$ concentration of ibogaine (Fig. 2 B). To determine the site specificity of the consequences of intra-VTA ibogaine, the compound was microinjected into the neighboring dopaminergic cell group of the substantia nigra. There was no effect of $10 \mu \mathrm{M}$ ibogaine on ethanol self-administration measured $3 \mathrm{hr}$ after treatment (Fig. 2C); hence the decrease in ethanol intake observed after microinjection of ibogaine into the VTA is mediated by this region and not by diffusion into the nearby substantia nigra.

\section{Systemic administration of ibogaine increases GDNF mRNA levels in the midbrain}

To identify the molecular mechanism that mediates the effects of ibogaine on ethanol intake, we used a small-scale expression array to study gene expression in the midbrain of mice that were injected with ibogaine. Administration of ibogaine $(40 \mathrm{mg} / \mathrm{kg}$, i.p.) significantly increased the mRNA expression of GDNF with an approximate twofold increase at the 1 and $12 \mathrm{hr}$ time points after injection (data not shown). Next, using RT-PCR, we confirmed these results by measuring the mRNA level of GDNF in mice and rats at various time points after systemic administration of ibogaine. Ibogaine $(40 \mathrm{mg} / \mathrm{kg}$ ) administration caused an increase in the expression of GDNF in the midbrain in both mice (Fig. 2D) and rats (Fig. 2E) up to $24 \mathrm{hr}$ after injection; hence, in the rat, the same dose of ibogaine that caused a reduction in ethanol intake (Fig. $1 A-D$ ) and ethanol-induced reinstatement (Fig. $1 E, F$ ) also caused an increase in the mRNA expression of GDNF.
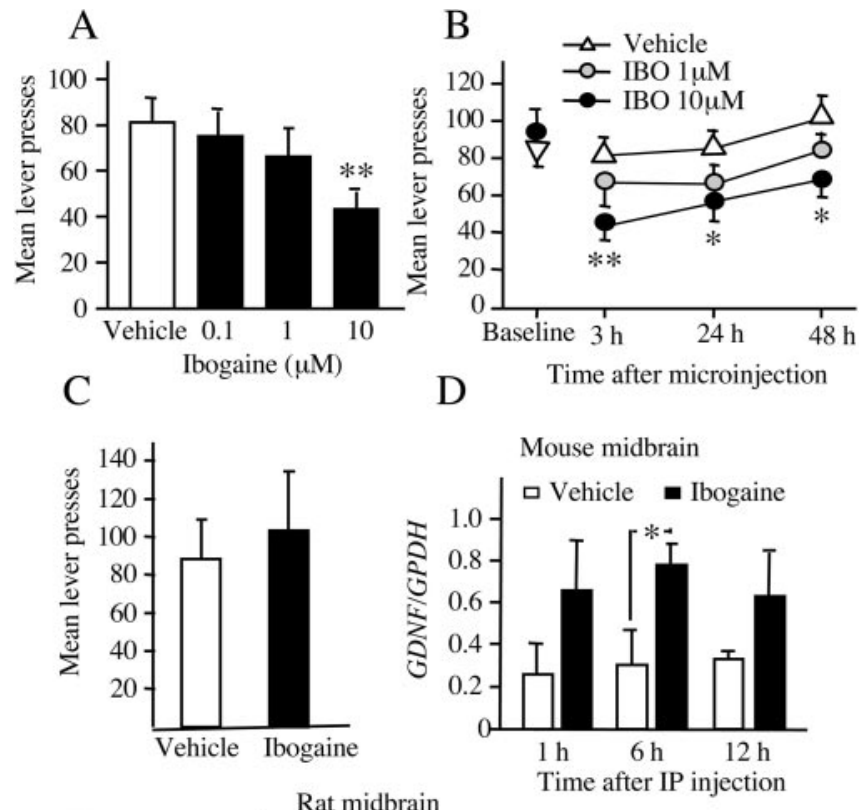

$\mathrm{E}$

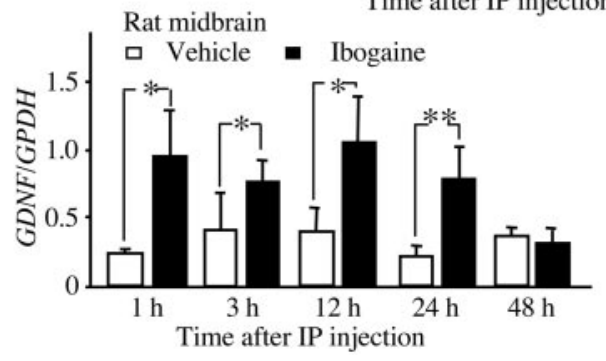

Figure 2. Intra-VTA microinjection of ibogaine decreases ethanol self-administration, and systemic ibogaine increases GDNF expression in a midbrain region that contains the VTA. $A, B$, Intra-VTA ibogaine decreased ethanol self-administration by rats. $A$, lbogaine $(0,0.1,1,10 \mu \mathrm{m}$; equivalent to $0,0.05,0.5,5.0 \mathrm{pmol}$ ) microinjected into the VTA $3 \mathrm{hr}$ before an ethanol selfadministration session dose-dependently decreased lever press responding $\left(F_{(3,27)}=5.90\right.$; $p<0.002)$. Data are shown as mean $\pm S E M .{ }^{* *} p<0.001$ compared with active lever responding after vehicle injection $(n=10)$. $B$, Time course of effect of intra-VTA ibogaine. The same subjects in $A$ were tested 24 and $48 \mathrm{hr}$ after ibogaine (IBO) treatment. There was no difference in responding on the day before treatment (Baseline) $\left(F_{(3,27)}=0.36 ; p=0.78\right)$. Ibogaine reduced responding for ethanol, and this reduction was long lasting (main effect of concentration: $F_{(3,54)}=8.62, p<0.001$; main effect of time: $F_{(2,54)}=6.76, p<0.006$; concentration $\times$ time interaction: $\left.F_{(6,54)}=0.26, p=0.95\right)$. The $10 \mu \mathrm{m}$ dose significantly reduced responding at all time points. The $0.1 \mu \mathrm{m}$ dose was omitted for clarity; responding after this dose did not differ from vehicle at any tested time point. Data are shown as mean \pm SEM. ${ }^{*} p<0.05$, ${ }^{* *} p<0.005$ compared with active lever responding after vehicle injection $(n=10)$. C, Ibogaine microinjected into the substantia nigra $3 \mathrm{hr}$ before an ethanol self-administration session did not affect ethanol lever press responding relative to vehicle microinjection (main effect of treatment: $F_{(1,7)}=0.59, p=0.47$; main effect of lever: $F_{(1,7)}=13.37, p<0.007$; treatment $\times$ lever interaction: $\left.F_{(1,7)}=0.38, P=0.56\right)$. Data are shown as mean $\pm \operatorname{SEM}(n=8) . D, E$, The midbrain region was excised 1, 6, or $12 \mathrm{hr}$ (mouse) and 1, 3, 24, and $48 \mathrm{hr}$ (rat) after intraperitoneal injection of $40 \mathrm{mg} / \mathrm{kg}$ ibogaine. The expression of GDNF and control GPDH in mouse (D) and rat $(E)$ was analyzed by RT-PCR. Histogram depicts the mean ratio (GDNF/GPDH) $\pm S D$ of $n=3(D), n=6(1,3$, and $12 \mathrm{hr})$, and $n=5(24$ and $48 \mathrm{hr})(E) .{ }^{*} p<0.05,{ }^{* *} p<0.01$ compared with saline injection.

\section{Ibogaine treatment does not result in cell death}

To confirm that the effects of ibogaine are not attributable to a neurotoxic effect of the drug, we examined the brains of mice $(n=2)$ injected with $40 \mathrm{mg} / \mathrm{kg}$ ibogaine and compared them with uninjected control mice $(n=2)$ using the Fluoro-Jade technique, a technique that has been used to identify ibogaine-induced cerebellar toxicity (Schmued and Hopkins, 2000). We scanned serial coronal sections from anterior forebrain to hindbrain of ibogaine-treated and control brains for brightly fluorescing (dy- 
A: Control

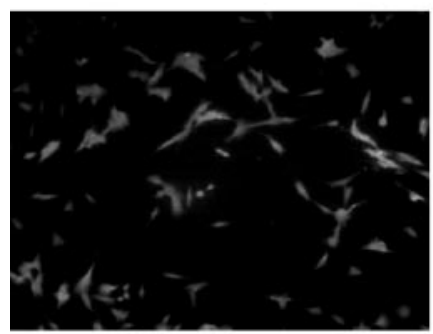

C: Latrunculin B

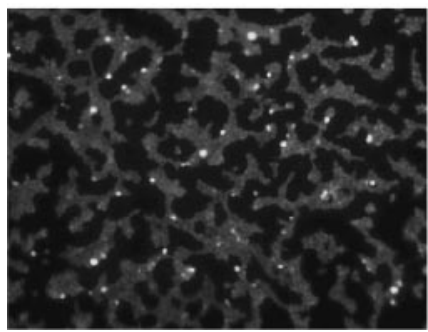

Figure 3. Ibogaine is not neurotoxic to cells in culture. $A-D, S H S Y 5 Y$ cells were treated with vehicle $(A), 10 \mu \mathrm{m}$ ibogaine for $24 \mathrm{hr}(B), 2 \mu \mathrm{m}$ Latrunculin $B(C)$, or the PI3 kinase inhibitor Wortmannin $(4 \mu \mathrm{m})$ for $90 \mathrm{~min}(D)$. Cell death was measured with Fluoro-Jade as described in Materials and Methods.

ing) neurons. Although myelin, ependymal cells, and choroid plexus were lightly stained, we observed no brightly fluorescing dying neurons in either control or ibogaine-treated brains (data not shown). Particular attention was paid to the midbrain, the region in which we found the increase in GDNF mRNA after ibogaine, and to the cerebellum, because cell death has been reported in the cerebellum after administration of high doses of ibogaine (O'Hearn and Molliver, 1993, 1997). The lack of staining that we observed is in concordance with previous data (Molinari et al., 1996; Schmued and Hopkins, 2000). The lack of ibogaine neurotoxicity was also confirmed in SHSY5Y cells treated with $10 \mu \mathrm{M}$ ibogaine for $24 \mathrm{hr}$. As positive controls, cells were treated with Wortmannin (PI3 kinase inhibitor) or Latrunculin B (actin polymerization inhibitor), which cause SHSY5Y cells to retract their processes, become rounded, and die. As shown in Figure 3, cell death is observed in both the Latrunculin B- and Wortmannin-treated cells as detected by the brightly fluorescing dying cells; however, there was no difference in FluoroJade staining in control or ibogaine-treated cultures, indicating that Fluoro-Jade is an effective cell-death marker.

\section{The GDNF signaling pathway is activated in SHSY5Y cells after exposure to ibogaine}

Because we found that ibogaine increased the expression of GNDF mRNA in the rodent midbrain, we tested whether ibogaine reduces ethanol consumption by activating the GDNF pathway within neurons in this brain region. GDNF promotes the survival of dopaminergic midbrain neurons (for review, see Airaksinen and Saarma, 2002), and the GDNF receptors GFR $\alpha 1$ and Ret are expressed in dopaminergic neurons, including within the VTA (Glazner et al., 1998; Sarabi et al., 2001). Therefore, we used the dopaminergic SHSY5Y human neuroblastoma cell line to determine the activities of ibogaine on GDNF expression, secretion, and signaling. Ibogaine induced dose-dependent (data not shown) and time-dependent (Fig. 4A) increases in GDNF expression that lasted up to $12 \mathrm{hr}$. Next, we examined whether the increase in GDNF mRNA levels leads to an increase in GDNF

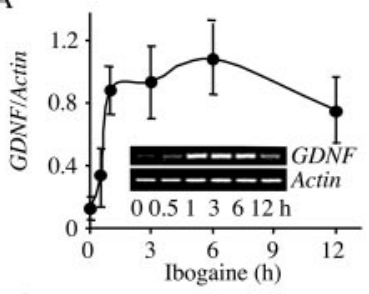

C

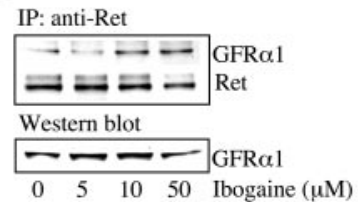

E

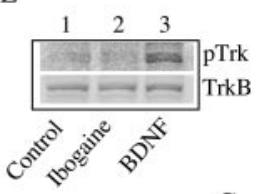

B

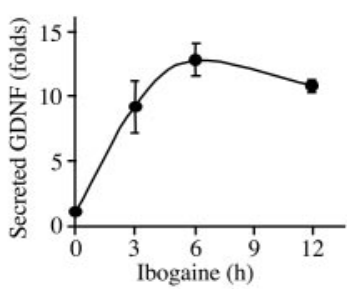

D

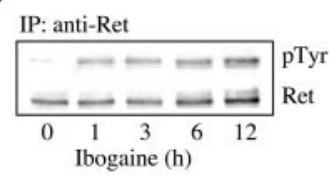

F

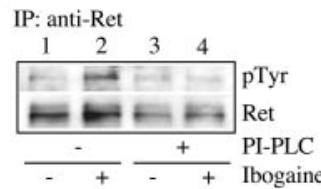

G

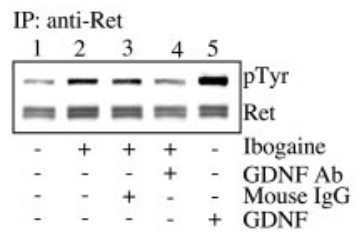

Figure 4. Ibogaine activates the GDNF pathway in SHSY5Y cells. A, Cells were treated with 10 $\mu \mathrm{m}$ ibogaine for the indicated times and lysed for total RNA isolation. Expression of GDNF and control actin was analyzed by RT-PCR $(n=4)$. B, Cells were treated with $10 \mu \mathrm{m}$ ibogaine for the indicated times. GDNF in the media was detected by an ELISA assay. Histogram depicts the mean \pm SD of GDNF secretion in three experiments. C, Cells were treated with the indicated concentrations of ibogaine for $3 \mathrm{hr}$. Ret was immunoprecipitated with anti-Ret antibodies, followed by Western blot analysis with anti-GFR $\alpha 1$ antibodies. The levels of GFR $\alpha 1$ in the homogenates were determined by Western blot analysis $(n=3)$. D, Cells were treated with 10 $\mu \mathrm{m}$ ibogaine for the indicated times. Ret was immunoprecipitated followed by Western blot analysis with anti-phosphotyrosine or anti-Ret antibodies $(n=3)$. E, Cells were treated with vehicle (lane 1) or $10 \mu \mathrm{m}$ ibogaine (lane 2) for $3 \mathrm{hr}$ or with $50 \mathrm{ng} / \mathrm{ml} \mathrm{BDNF}$ for $10 \mathrm{~min}$ (lane 3). Trk phosphorylation was analyzed by Western blot analysis with anti-phospho-Trk antibodies. The levels of TrkB were also determined by Western blot analysis $(n=3)$. $F$, Cells were preincubated with $0.3 \mathrm{U} / \mathrm{mI} \mathrm{PI-PLC}$ for $1 \mathrm{hr}$ (lanes 3 and 4). Cells were then washed and treated without (lanes 1 and 3) or with (lanes 2 and 4) $10 \mu \mathrm{m}$ ibogaine for $3 \mathrm{hr}$. Ret phosphorylation was determined as described above ( $n=4)$. $G$, Cells were treated for $3 \mathrm{hr}$ with vehicle (lane 1), $10 \mu \mathrm{m}$ ibogaine (lane 2), $10 \mu \mathrm{m}$ ibogaine plus $10 \mu \mathrm{g} / \mathrm{ml}$ of mouse lgG (lane 3), or $10 \mu \mathrm{m}$ ibogaine plus antiGDNF neutralizing antibodies (lane 4). Treatment with $50 \mathrm{ng} / \mathrm{ml}$ GDNF was used as a positive control (lane 5). The cells were lysed and Ret phosphorylation was analyzed as described above $(n=3)$.

secretion. To do so, we measured GDNF levels in the media of cells treated with ibogaine and found that GDNF accumulated in the media in a time-dependent manner consistent with the time course for mRNA increases (Fig. 4B).

Activation of the GDNF pathway is initiated after ligation of GDNF with GFR $\alpha 1$ leading to the association of Ret with GFR $\alpha 1$, and the consequent autophosphorylation, and thus activation, of Ret (Jing et al., 1996; Treanor et al., 1996); hence, we assessed whether ibogaine induces the association of Ret with GFR $\alpha 1$. Ibogaine treatment increased Ret association with GFR $\alpha 1$ (Fig. $4 C$, top), and this increased association was not caused by increased GFR $\alpha 1$ protein levels (Fig. $4 C$, bottom). Next, we determined whether the ibogaine-induced association of Ret with GFR $\alpha 1$ leads to the activation of the GDNF pathway by measuring the levels of phospho-Ret in the absence or presence of ibogaine. Ibogaine induced Ret phosphorylation in dose-dependent 


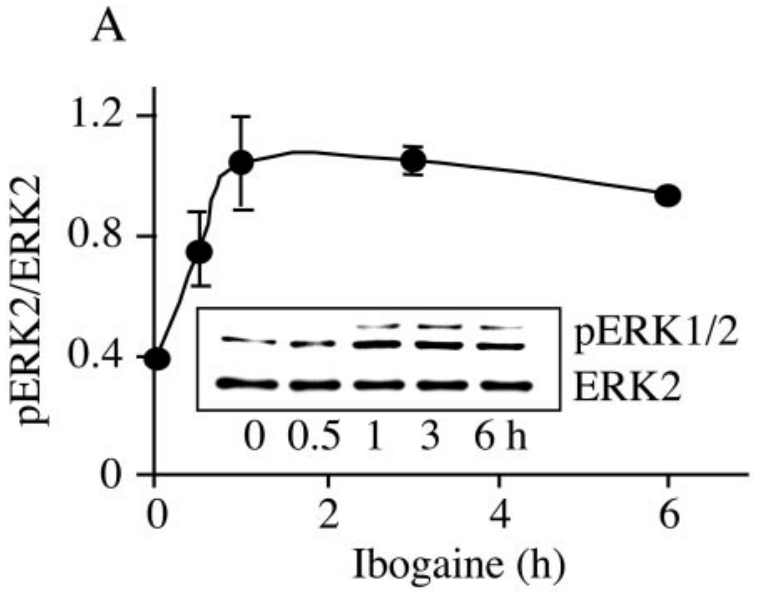

B

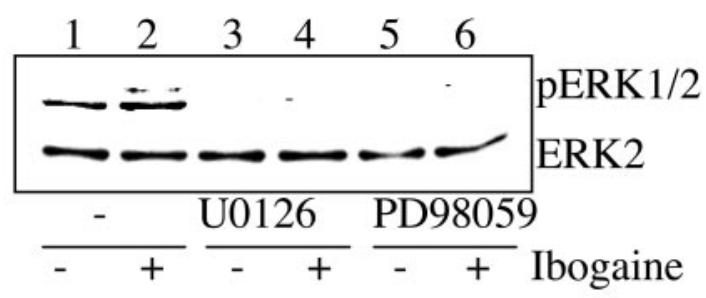

C

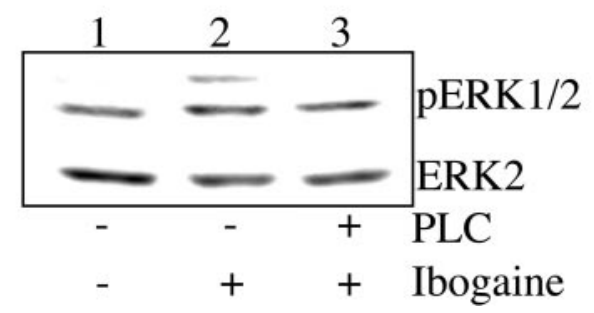

Figure 5. Ibogaine activates the MAPK signaling pathway. A, SHSY5Y cells were treated with $10 \mu \mathrm{m}$ ibogaine for the indicated times. ERK2 and phosphoERK $1 / 2$ (pERK1/2) were detected by Western blot analysis with anti-ERK2 and anti-pERK1/2 antibodies, respectively. Line graph depicts the mean ratio (pERK2/ERK2) $\pm S D$ of three experiments. $B$, Cells were preincubated with the inhibitors U0126 (20 $\mu \mathrm{m}$ ) (lanes 3 and 4) and PD58089 (40 $\mu \mathrm{m}$ ) (lanes 5 and 6) for 30 min and then treated without (lanes 1, 3, and 5) or with (lanes 2, 4, and 6) $10 \mu \mathrm{m}$ ibogaine for $3 \mathrm{hr}(n=3)$. C, Cells were preincubated with $0.3 \mathrm{U} / \mathrm{ml} \mathrm{PI-PLC} \mathrm{for} 1 \mathrm{hr}$ (lane 3). Cells were then washed and treated without (lanes 1) or with (lanes 2 and 3) $10 \mu \mathrm{m}$ ibogaine for $3 \mathrm{hr}(n=3)$.

(data not shown) and time-dependent manners (Fig. 4D). We found no change in the phosphorylation state of another growth factor receptor tyrosine kinase, Trk, in the presence of ibogaine (Fig. $4 E$ ). GFR $\alpha 1$ is a glycosyl-phosphatidylinositol-anchored protein that can be hydrolyzed by PI-PLC (Jing et al., 1996; Treanor et al., 1996). If ibogaine activates Ret by inducing the association of Ret with GFR $\alpha 1$, then ibogaine-induced Ret phosphorylation should be prevented by PI-PLC. Preincubation of the cells with PI-PLC abolished ibogaine-induced Ret phosphorylation (Fig. $4 F$ ). Ret phosphorylation induced by ibogaine was also inhibited in the presence of anti-GDNF neutralizing antibodies (Fig. 4G, lane 2 vs 4 ). Finally, we determined whether downstream signaling cascades known to be activated by GDNF (Trupp et al., 1999; Hayashi et al., 2000) also were activated in the presence of ibogaine. We measured the phosphorylation, and thus activation state, of ERK1/2, also named p42/44 mitogenactivated protein kinases (p42/44 MAPK). We found that ibogaine induced the phosphorylation of ERK1/2, and the activation lasted up to 6 hr (Fig. 5A). Furthermore, U0126 and PD98059, two inhibitors specific for MAPK/ERK kinase 1, a kinase upstream of ERK1/2, blocked ERK1/2 phosphorylation induced by ibogaine (Fig. 5B). Finally, preincubation with PI-PLC abolished ibogaine-induced ERK1/2 phosphorylation (Fig. 5C), suggesting that ibogaine-induced ERK1/2 phosphorylation is mediated by the association of the GDNF receptors GFR $\alpha 1$ and Ret.

\section{Ibogaine treatment reduces ethanol self-administration via GDNF}

Because ibogaine administration increased GDNF expression in the midbrain, we tested whether direct microinjection of GDNF into the VTA would itself decrease ethanol self-administration. Microinjection of $5 \mu \mathrm{g} / \mu \mathrm{l}$ GDNF into the VTA $10 \mathrm{~min}$ before placement in the operant chamber significantly reduced responding for ethanol (Fig. 6A), without affecting the latency to the first press (Table 1). Next, we tested whether the behavioral effects of ibogaine would be inhibited by anti-GDNF neutralizing antibodies infused into the VTA (Messer et al., 2000). Two subcutaneous osmotic minipumps were attached to bilateral cannulas aimed at the VTA to continuously infuse either anti-GDNF neutralizing antibodies or control mouse IgG for 2 weeks. During the infusion of the antibody, ethanol intake was measured in daily operant self-administration sessions. Neither the infusion of vehicle (data not shown) nor the infusion of control mouse IgG altered ethanol self-administration (Fig. 6B); however, infusion of anti-GDNF neutralizing antibodies significantly attenuated the ability of ibogaine to decrease ethanol self-administration both 3 and $24 \mathrm{hr}$ after ibogaine administration (Fig. 6B). Specifically, $3 \mathrm{hr}$ after injection of ibogaine $(40 \mathrm{mg} / \mathrm{kg}$, i.p.), control subjects decreased responding for ethanol by $79.1 \%( \pm 0.05)$, whereas only a $39.1 \%( \pm 0.13)$ decrease was observed in animals receiving the anti-GDNF neutralizing antibodies (Fig. 6B); however, inactive lever responding was unchanged (data not shown). Together, these results suggest that the effects of ibogaine on ethanol consumption are mediated by GDNF.

\section{Discussion}

We found that ibogaine reduces ethanol consumption and that this effect is likely caused by the actions of ibogaine within the VTA, because microinjection of ibogaine into the VTA, but not the substantia nigra, also decreased ethanol self-administration. Furthermore, systemic administration of ibogaine increased expression of GDNF in the midbrain. In a dopaminergic neuroblastoma cell line, ibogaine-induced increases in the expression of GDNF led to increased secretion of GDNF and subsequent activation of the GDNF pathway. Finally, the in vivo effects of ibogaine were mimicked by intra-VTA microinjection of GDNF and were diminished when ibogaine was given in the presence of anti-GDNF neutralizing antibodies infused into the VTA. These findings collectively suggest that ibogaine decreases ethanol intake by increasing the level of GDNF in the VTA.

\section{Ibogaine attenuates ethanol self-administration}

A previous study found that ibogaine decreased ethanol consumption in ethanol-preferring rats in the two-bottle preference paradigm (Rezvani et al., 1995). Our initial studies were designed to replicate these findings in an outbred line of rats and to extend them to the operant self-administration procedure. In agreement with Rezvani et al. (1995), we found that ibogaine decreases ethanol intake whether the ethanol is available continuously on the home cage or after lever-press responding for a limited time each day. We also tested the effects of acute ibogaine on responding for ethanol in a model of relapse, in which subjects were granted 
A
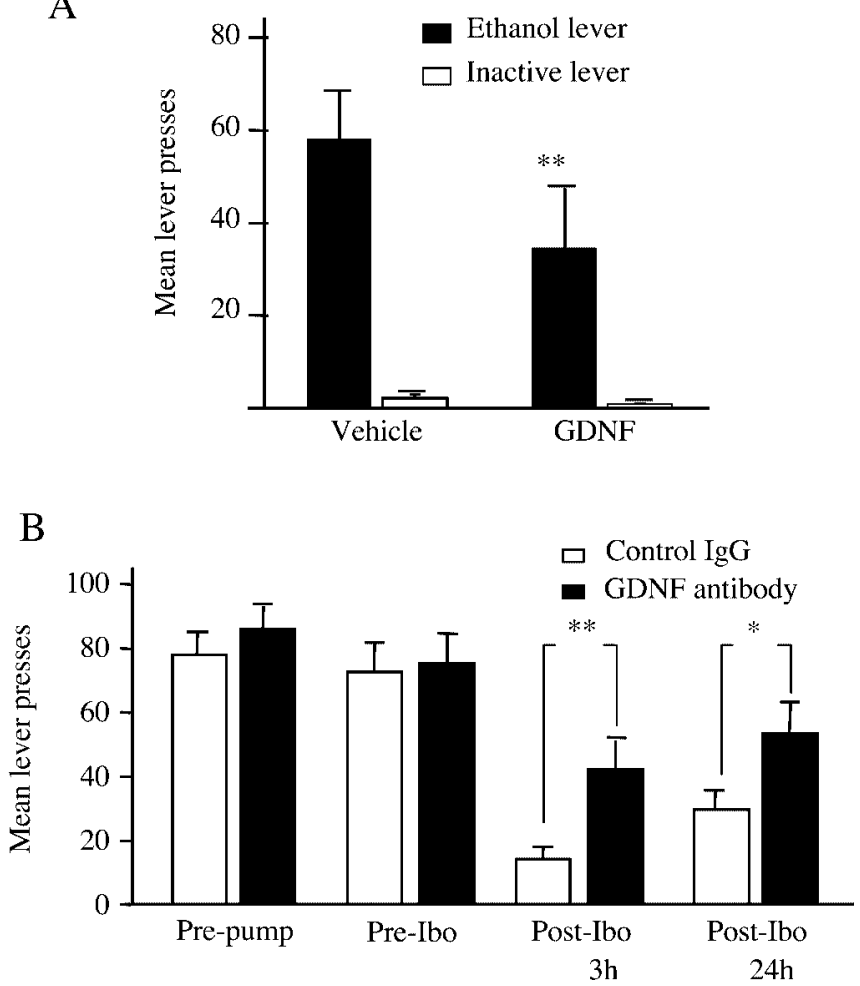

Figure 6. Intra-VTA infusion of GNDF mimics the effects of ibogaine, and anti-GDNF neutralizing antibodies attenuate the effects of ibogaine on ethanol self-administration. A, GDNF (5 $\mu \mathrm{g} / \mu \mathrm{l})$ microinjected into the VTA $10 \mathrm{~min}$ before an ethanol self-administration session decreased mean lever press responding relative to vehicle (main effect of treatment: $F_{(1,7)}=8.38$, $p<0.03$; main effect of lever: $F_{(1,7)}=17.10, p<0.005$; treatment $\times$ lever interaction: $\left.F_{(1,7)}=5.88, p<0.05\right) .{ }^{* *} p<0.003$. The data are shown as mean lever presses $\pm \operatorname{SEM}(n=$ 8). $B$, Rats received continuous infusion for $14 \mathrm{~d}$ of anti-GDNF neutralizing antibodies or mouse IgG (600 ng/12 $\mu$ l per side per day) into the VTA via osmotic minipumps. Responding for ethanol reinforcement was measured before and after antibody infusion in daily $1 \mathrm{hr}$ ethanol self-administration sessions. The effect of ibogaine $(40 \mathrm{mg} / \mathrm{kg}$, i.p.) was tested on the 10 th day of antibody infusion, and self-administration behavior was measured for three additional daily sessions. "Pre-pump" represents the mean of the last three training sessions before antibody infusion; "Pre-lbo" represents the mean of the last three training sessions after antibody infusion and before ibogaine injection. There was no effect of intra-VTA anti-GDNF antibody infusion on baseline levels of ethanol self-administration (Pre-pump vs Pre-lbo) $\left(F_{(1,15)}=0.244\right.$; $p=0.63)$. When the Pre-lbo baseline was compared with data obtained 3 and $24 \mathrm{hr}$ after ibogaine injection (Post-lbo), there was a significant effect of antibody treatment $\left(F_{(1,30)}=\right.$ $5.15 ; p<0.04)$ and a significant effect of time $\left(F_{(2,30)}=23.1 ; p<0.001\right)$. Although ibogaine treatment decreased responding in both groups, the decrease in responding is significantly greater in the control mouse lgG group $(n=9)$ than in subjects treated with anti-GDNF neutralizing antibodies $(n=8)$. ${ }^{* *} p<0.02$; ${ }^{*} p<0.05$. The data are shown as mean lever presses \pm SEM.

access to ethanol after 2 weeks of extinction. This protocol is similar to alcohol deprivation procedures used to study the neurobiology of ethanol relapse and craving, in which rats demonstrate enhanced intake after a period of abstinence (Koob et al., 1998; McBride and Li, 1998). This enhanced intake may be analogous to the avid ethanol consumption seen among human alcoholics after relapse. We found that ethanol intake was increased significantly after 2 weeks of extinction, compared with preextinction baseline levels: ibogaine reduced the enhanced ethanol intake to baseline levels. Interestingly, human anecdotal reports also suggest a decrease in craving and relapse to addictive drugs after ibogaine intake (Mash et al., 2000). Together, these findings indicate that ibogaine reduces ethanol intake, suggesting that the identification of its molecular mechanism of action for this effect may be beneficial.
For several reasons, it is unlikely that the reduction of ethanol intake observed after $40 \mathrm{mg} / \mathrm{kg}$ ibogaine is caused by nonspecific activities of the drug. First, we found that ibogaine did not reduce preference for a sucrose solution, in agreement with a previous study that found no effect of $40 \mathrm{mg} / \mathrm{kg}$ ibogaine on intake of a sucrose/saccharin solution in rats (Blackburn and Szumlinski, 1997). Second, it is unlikely that changes in locomotor activity can explain the decrease in ethanol consumption. In our experiments, we tested the effects of ibogaine on ethanol intake $3 \mathrm{hr}$ after ibogaine injection; a previous report in rats found that ibogaine does not affect locomotor activity 3-4 hr after injection (Maisonneuve et al., 1997). In addition, we found no effect of ibogaine on inactive lever responding in the operant selfadministration procedure. Although low responding on the inactive lever precludes examination of activity decreases, these findings suggest that ibogaine did not produce nonspecific activity increases. We also found no effect of ibogaine on the latency to the first lever press, indicating that ibogaine-treated subjects were not impaired in the initiation or production of lever-press responding. Third, there is no evidence that ibogaine-induced decreases in ethanol intake are subsequent to a neurotoxic effect. We found no evidence for ibogaine-induced neurotoxcitiy in the brain or in a neuronal cell line, in concordance with Molinari et al. (1996); hence, it is unlikely that the reduction of ethanol intake by ibogaine here resulted from nonspecific actions on consumption or motor activity or from neurotoxic effects.

\section{The VTA is the site of action for the reduction of ethanol} intake and induction of GDNF mRNA by ibogaine

Although attenuation of ethanol self-administration by $40 \mathrm{mg} / \mathrm{kg}$ ibogaine in rats is not likely to reflect nonspecific alterations in behavior, the use of ibogaine for treatment of humans is problematic given the uncertainties surrounding the doses that might induce neurotoxicity and the fact that it is a hallucinogen. Therefore, in the second part of our study we set out to determine a molecular mechanism of ibogaine action against ethanol selfadministration. We reasoned that ibogaine might alter signaling pathways within the "addiction" neurocircuitry. We found that microinjection of ibogaine into the VTA reduced ethanol intake, suggesting that the VTA is a primary site of action for systemic administration of ibogaine. This suggestion was strengthened by the lack of effect of ibogaine microinjected into the neighboring dopaminergic cells comprising the substantia nigra.

The VTA was further implicated as the site of action of ibogaine by the finding that ibogaine increased GDNF expression in the midbrain, a region that includes the VTA. This result suggests that increased GDNF expression in the midbrain mediates the effects of ibogaine on ethanol intake. Because the increase in GDNF was not observed $48 \mathrm{hr}$ after ibogaine injection but ethanol consumption was still reduced, activation of the pathway downstream to GDNF likely persists longer than the changes in GDNF expression.

\section{Ibogaine increases GDNF expression and signaling in a dopaminergic cell line}

Ibogaine also increased expression of GDNF in SHSY5Y cultured cells, suggesting that this dopaminergic cell line is an appropriate model for examining the effects of ibogaine on GDNF signaling. In SHSY5Y cells, the ibogaine-induced increase in GDNF expression led to increased GDNF secretion and activation of the GDNF pathway. Specifically, ibogaine increased the activity of the MAPK pathway, which has been reported to be activated via GDNF (Besset et al., 2000; Hayashi et al., 2000). Interestingly, 
activation of the MAPK pathway was shown previously to result in the inhibition of A-type potassium channels (Yuan et al., 2002), and GDNF has been reported to enhance the excitability of midbrain dopaminergic neurons by inhibiting the A-type potassium channels (Yang et al., 2001). Chronic ethanol inhibits the excitability of VTA neurons (Bailey et al., 1998), and the firing rates of dopaminergic cells are markedly reduced in the early abstinence period after chronic ethanol consumption (Bailey et al., 2001). These findings suggest that ibogaine, via GDNF, may reverse the actions of ethanol in the VTA by inhibiting the activity of A-type potassium channels, thus enhancing VTA firing.

Although ibogaine injection induced expression of GDNF mRNA in rodent midbrain, the cellular source of the GDNF mRNA is unknown. Because GDNF is expressed in both glia and neurons (Airaksinen and Saarma, 2002), at this point we cannot exclude the possibility that ibogaine increases the expression of GDNF in astrocytes; however, the finding that ibogaine also induced expression of GDNF in SHSY5Y cells, a dopaminergic neuroblastoma line (Biedler et al., 1978), indicates that the source of GDNF may be neuronal.

\section{The actions of ibogaine are long lasting}

Ibogaine induction of GDNF expression lasted for at least $12 \mathrm{hr}$ in cultured cells and in vivo. In addition, the effects of ibogaine on ethanol self-administration were long lasting. The half-life of ibogaine is reported to be $\sim 1-2 \mathrm{hr}$, whereas its metabolite, noribogaine, is detected at high concentrations within $24 \mathrm{hr}$ after administration (Mash et al., 1998; Glick and Maisonneuve, 2000). It is therefore possible that noribogaine initiates and/or maintains GDNF expression in the brain up to $24 \mathrm{hr}$ after injection. Interestingly, noribogaine reduces cocaine and morphine selfadministration (Glick et al., 1996), suggesting that the efficacy of ibogaine against drugs of abuse, including alcohol, may result from this metabolite. Another possible mechanism for the longlasting effects of ibogaine is that the initial increase in GDNF expression induced by ibogaine is followed by autocrine regulation of the expression of the growth factor (D.-Y. He, D. Ron, unpublished results).

\section{GDNF counters the effects of ethanol and other drugs of abuse}

Our finding that intra-VTA GDNF reduces ethanol selfadministration agrees with previous findings that GDNF counteracts the effects of drugs of abuse. For example, GDNF prevents ethanol-induced apoptosis in a neuroblastoma cell line (McAlhany et al., 2000). In addition, intra-VTA infusion of GDNF reverses morphine-induced increases in protein levels of $\mathrm{TH}$ (Messer et al., 2000). Intra-VTA GDNF treatment also blocks and reverses the biochemical effects of cocaine and blocks the rewarding effects of cocaine measured by the conditioned place preference test (Messer et al., 2000). Conversely, chronic exposure to drugs of abuse and ethanol decreases GDNF levels. Prolonged exposure to ethanol decreases GDNF secretion in developing cerebellum (McAlhany et al., 1999). Chronic exposure to cocaine and morphine decreases Ret phosphorylation in the VTA (Messer et al., 2000). Because exogenous administration of GDNF blocks the effects of drugs of abuse, including ethanol, it is plausible that endogenous GDNF systems may counter the effects of these drugs and that ibogaine acts to inhibit intake of stimulants, opiates, and ethanol by enhancing this protective pathway.

\section{Conclusions}

In conclusion, we have identified GDNF as a candidate molecule that mediates, at least in part, the effects of ibogaine on ethanol consumption. Therefore, this study suggests that the development of agents that upregulate the GDNF pathway may be useful in the treatment of drug and alcohol abuse.

\section{References}

Airaksinen MS, Saarma M (2002) The GDNF family: signaling, biological functions and therapeutic value. Nat Rev Neurosci 3:383-394.

Alper KR, Lotsof HS, Frenken GM, Luciano DJ, Bastiaans J (1999) Treatment of acute opioid withdrawal with ibogaine. Am J Addict 8:234-242.

Bailey CP, Manley SJ, Watson WP, Wonnacott S, Molleman A, Little HJ (1998) Chronic ethanol administration alters activity in ventral tegmental area neurons after cessation of withdrawal hyperexcitability. Brain Res 803:144-152.

Bailey CP, O'Callaghan MJ, Croft AP, Manley SJ, Little HJ (2001) Alterations in mesolimbic dopamine function during the abstinence period following chronic ethanol consumption. Neuropharmacology 41:989-999.

Balkowiec A, Katz DM (2000) Activity-dependent release of endogenous brain-derived neurotrophic factor from primary sensory neurons detected by ELISA in situ. J Neurosci 20:7417-7423.

Berhow MT, Russell DS, Terwilliger RZ, Beitner-Johnson D, Self DW, Lindsay RM, Nestler EJ (1995) Influence of neurotrophic factors on morphine- and cocaine-induced biochemical changes in the mesolimbic dopamine system. Neuroscience 68:969-979.

Besset V, Scott RP, Ibanez CF (2000) Signaling complexes and proteinprotein interactions involved in the activation of the Ras and phosphatidylinositol 3-kinase pathways by the c-Ret receptor tyrosine kinase. J Biol Chem 275:39159-39166.

Biedler JL, Roffler-Tarlov S, Schachner M, Freedman LS (1978) Multiple neurotransmitter synthesis by human neuroblastoma cell lines and clones. Cancer Res 38:3751-3757.

Blackburn JR, Szumlinski KK (1997) Ibogaine effects on sweet preference and amphetamine induced locomotion: implications for drug addiction. Behav Brain Res 89:99-106.

Cappendijk SL, Dzoljic MR (1993) Inhibitory effects of ibogaine on cocaine self-administration in rats. Eur J Pharmacol 241:261-265.

Charlton ME, Sweetnam PM, Fitzgerald LW, Terwilliger RZ, Nestler EJ, Duman RS (1997) Chronic ethanol administration regulates the expression of GABAA receptor alpha 1 and alpha 5 subunits in the ventral tegmental area and hippocampus. J Neurochem 68:121-127.

Dworkin SI, Gleeson S, Meloni D, Koves TR, Martin TJ (1995) Effects of ibogaine on responding maintained by food, cocaine and heroin reinforcement in rats. Psychopharmacology (Berl) 117:257-261.

Ferraro TN, Carrozza DP, Vogel WH (1991) In vivo microdialysis study of brain ethanol concentrations in rats following oral self-administration. Alcohol Clin Exp Res 15:504-507.

Glazner GW, Mu X, Springer JE (1998) Localization of glial cell line-derived neurotrophic factor receptor alpha and c-ret mRNA in rat central nervous system. J Comp Neurol 391:42-49.

Glick SD, Maisonneuve IM (2000) Development of novel medications for drug addiction. The legacy of an African shrub. Ann NY Acad Sci 909:88-103.

Glick SD, Rossman K, Rao NC, Maisonneuve IM, Carlson JN (1992) Effects of ibogaine on acute signs of morphine withdrawal in rats: independence from tremor. Neuropharmacology 31:497-500.

Glick SD, Pearl SM, Cai J, Maisonneuve IM (1996) Ibogaine-like effects of noribogaine in rats. Brain Res 713:294-297.

Hayashi H, Ichihara M, Iwashita T, Murakami H, Shimono Y, Kawai K, Kurokawa K, Murakumo Y, Imai T, Funahashi H, Nakao A, Takahashi M (2000) Characterization of intracellular signals via tyrosine 1062 in RET activated by glial cell line-derived neurotrophic factor. Oncogene 19:4469-4475.

Jing S, Wen D, Yu Y, Holst PL, Luo Y, Fang M, Tamir R, Antonio L, Hu Z, Cupples R, Louis JC, Hu S, Altrock BW, Fox GM (1996) GDNF-induced activation of the ret protein tyrosine kinase is mediated by GDNFR-alpha, a novel receptor for GDNF. Cell 85:1113-1124.

Koob GF (2000) Animal models of craving for ethanol. Addiction 95:S73-S81. 
Koob GF, Sanna PP, Bloom FE (1998) Neuroscience of addiction. Neuron 21:467-476

Maisonneuve IM, Visker KE, Mann GL, Bandarage UK, Kuehne ME, Glick SD (1997) Time-dependent interactions between iboga agents and cocaine. Eur J Pharmacol 336:123-126.

Mash DC, Kovera CA, Buck BE, Norenberg MD, Shapshak P, Hearn WL, Sanchez-Ramos J (1998) Medication development of ibogaine as a pharmacotherapy for drug dependence. Ann NY Acad Sci 844:274-292.

Mash DC, Kovera CA, Pablo J, Tyndale RF, Ervin FD, Williams IC, Singleton EG, Mayor M (2000) Ibogaine: complex pharmacokinetics, concerns for safety, and preliminary efficacy measures. Ann NY Acad Sci 914:394-401.

McAlhany Jr RE, Miranda RC, Finnell RH, West JR (1999) Ethanol decreases glial-derived neurotrophic factor (GDNF) protein release but not mRNA expression and increases GDNF-stimulated Shc phosphorylation in the developing cerebellum. Alcohol Clin Exp Res 23:1691-1697.

McAlhany Jr RE, West JR, Miranda RC (2000) Glial-derived neurotrophic factor (GDNF) prevents ethanol-induced apoptosis and JUN kinase phosphorylation. Brain Res Dev Brain Res 119:209-216.

McBride WJ, Li TK (1998) Animal models of alcoholism: neurobiology of high alcohol-drinking behavior in rats. Crit Rev Neurobiol 12:339-369.

Messer CJ, Eisch AJ, Carlezon Jr WA, Whisler K, Shen L, Wolf DH, Westphal H, Collins F, Russell DS, Nestler EJ (2000) Role for GDNF in biochemical and behavioral adaptations to drugs of abuse. Neuron 26:247-257.

Molinari HH, Maisonneuve IM, Glick SD (1996) Ibogaine neurotoxicity: a re-evaluation. Brain Res 737:255-262.

O'Hearn E, Molliver ME (1993) Degeneration of Purkinje cells in parasagittal zones of the cerebellar vermis after treatment with ibogaine or harmaline. Neuroscience 55:303-310.

O'Hearn E, Molliver ME (1997) The olivocerebellar projection mediates ibogaine-induced degeneration of Purkinje cells: a model of indirect, trans-synaptic excitotoxicity. J Neurosci 17:8828-8841.

Ortiz J, Fitzgerald LW, Charlton M, Lane S, Trevisan L, Guitart X, Shoemaker W, Duman RS, Nestler EJ (1995) Biochemical actions of chronic ethanol exposure in the mesolimbic dopamine system. Synapse 21:289-298.

Popik P, Layer RT, Skolnick P (1995) 100 years of ibogaine: neurochemical and pharmacological actions of a putative anti-addictive drug. Pharmacol Rev 47:235-253.
Rezvani AH, Overstreet DH, Lee YW (1995) Attenuation of alcohol intake by ibogaine in three strains of alcohol-preferring rats. Pharmacol Biochem Behav 52:615-620.

Sarabi A, Hoffer BJ, Olson L, Morales M (2001) GFRalpha-1 mRNA in dopaminergic and nondopaminergic neurons in the substantia nigra and ventral tegmental area. J Comp Neurol 441:106-117.

Schmued LC, Hopkins KJ (2000) Fluoro-Jade: novel fluorochromes for detecting toxicant-induced neuronal degeneration. Toxicol Pathol 28:91-99.

Sershen H, Hashim A, Lajtha A (1994) Ibogaine reduces preference for cocaine consumption in $\mathrm{C} 57 \mathrm{BL} / 6 \mathrm{By}$ mice. Pharmacol Biochem Behav 47:13-19.

Sheppard SG (1994) A preliminary investigation of ibogaine: case reports and recommendations for further study. J Subst Abuse Treat 11:379-385.

Spanagel R, Weiss F (1999) The dopamine hypothesis of reward: past and current status. Trends Neurosci 22:521-527.

Treanor JJ, Goodman L, de Sauvage F, Stone DM, Poulsen KT, Beck CD, Gray C, Armanini MP, Pollock RA, Hefti F, Phillips HS, Goddard A, Moore MW, Buj-Bello A, Davies AM, Asai N, Takahashi M, Vandlen R, Henderson CE, Rosenthal A (1996) Characterization of a multicomponent receptor for GDNF. Nature 382:80-83.

Trupp M, Scott R, Whittemore SR, Ibanez CF (1999) Ret-dependent and -independent mechanisms of glial cell line-derived neurotrophic factor signaling in neuronal cells. J Biol Chem 274:20885-20894.

Vastag B (2002) Addiction treatment strives for legitimacy. JAMA 288: 3096-3101.

Weiss F, Lorang MT, Bloom FE, Koob GF (1993) Oral alcohol selfadministration stimulates dopamine release in the rat nucleus accumbens: genetic and motivational determinants. J Pharmacol Exp Ther 267:250-258

Yang F, Feng L, Zheng F, Johnson SW, Du J, Shen L, Wu CP, Lu B (2001) GDNF acutely modulates excitability and A-type $\mathrm{K}(+)$ channels in midbrain dopaminergic neurons. Nat Neurosci 4:1071-1078.

Yuan LL, Adams JP, Swank M, Sweatt JD, Johnston D (2002) Protein kinase modulation of dendritic $\mathrm{K}+$ channels in hippocampus involves a mitogen-activated protein kinase pathway. J Neurosci 22:4860-4868. 